Research Article

\title{
Effect of Biochar on Soil Properties, Soil Loss, and Cocoyam Yield on a Tropical Sandy Loam Alfisol
}

\author{
Aruna Olasekan Adekiya $\mathbb{D}^{1},{ }^{1}$ Taiwo Michael Agbede, ${ }^{2}$ Adeniyi Olayanju, ${ }^{3}$ \\ Wutem Sunny Ejue, ${ }^{1}$ Timothy A. Adekanye, ${ }^{3}$ Titilayo Tolulope Adenusi, ${ }^{1}$ \\ and Jerry Femi Ayeni ${ }^{3}$ \\ ${ }^{1}$ College of Agricultural Sciences, Landmark University, P.M.B. 1001, Omu-Aran, Kwara, Nigeria \\ ${ }^{2}$ Department of Crop, Soil and Pest Management Technology, Rufus Giwa Polytechnic, P.M.B. 1019, Owo, Ondo, Nigeria \\ ${ }^{3}$ Department of Agricultural \& Biosystem Engineering, Landmark University, P.M.B. 1001, Omu-Aran, Kwara, Nigeria \\ Correspondence should be addressed to Aruna Olasekan Adekiya; adekiya2009@yahoo.com
}

Received 3 October 2019; Revised 21 November 2019; Accepted 11 December 2019; Published 25 February 2020

Academic Editor: Yasemin Kavdir

Copyright (c) 2020 Aruna Olasekan Adekiya et al. This is an open access article distributed under the Creative Commons Attribution License, which permits unrestricted use, distribution, and reproduction in any medium, provided the original work is properly cited.

\begin{abstract}
Among agricultural soil amendment that can enhance crop productivity and soil sustainability is biochar. Hence, two-year field experiments were conducted on a sandy loam Alfisol at Owo, southwest Nigeria, to evaluate the effects of biochar produced from hardwood on soil physical and chemical characteristics, erosion potential, and cocoyam (Xanthosoma sagittifolium (L.) Schott) yield. The study was a $2 \times 4$ factorial experiment with two years (2017 and 2018) and four biochar levels ( 0 (control), 10, 20, and $30 \mathrm{t}$ $\left.\mathrm{ha}^{-1}\right)$. The treatments were laid out in a randomized complete block design with three replications. Results indicated that biochar application significantly in both years improved yield of cocoyam and soil physical (bulk density, porosity, moisture content, mean weight diameter (MWD) of soil aggregates, dispersion ratio, and infiltration rate) and chemical (soil organic matter, $\mathrm{pH}, \mathrm{N}$, $\mathrm{P}, \mathrm{K}, \mathrm{Ca}, \mathrm{Mg}$, and CEC) properties and erosion resistance. Soil characteristics and cocoyam yield improved with level of biochar from 0-30 $\mathrm{t} \mathrm{ha}^{-1}$. When 2018 is compared with 2017 in term of soil loss, in the amended plots, 2018 reduced soil loss by 7.4, 20, and $73.5 \%$, respectively, for 10,20 , and $30 \mathrm{tha}^{-1}$ biochar, whereas there was an increase of $2.7 \%$ soil loss in the control plot in 2018 compared with 2017. Therefore, application rate of $30 \mathrm{t} \mathrm{ha}^{-1}$ biochar is considered as suitable for severely degraded soil because this application rate efficiently improves cocoyam yield and soil properties and reduces soil loss.
\end{abstract}

\section{Introduction}

One of the major constraints to crop production in the tropics is soil-related problems. In Nigeria, the largest soil order-Alfisol-is faced with a lot of unfavourable challenges such as low fertility, soil acidity, weak structure and high susceptibility to crusting, compaction, and accelerated erosion [1]. Also, the expansion of agriculture into marginal areas, deforestations, the shortening or elimination of fallows, inappropriate farming practices, and low input inevitably have several environmental and economic impacts on tropical soils where the resilience ability of the soil is limited [2]. Therefore, the avoidance of soil loss by improved management of the natural resources is important to combat low agricultural production, food insecurity, and the increase in level of poverty in tropical countries [3].

Among agricultural soil amendment that can enhance agricultural productivity and soil sustainability is biochar. Biochar is the product of pyrolysis of organic materials in the absence of oxygen and at high temperature [4]. Until now, uncharred amendments were being used to improve the fertility/productivity of the soil and improve organic matter content [5]. However, the decomposition of soil organic matter is too high [6] especially under tropical condition with high temperature, and therefore biochar provides an additional soil management option. Due to its relative recalcitrant after amendment, biochar can remain in the soil for many years. This contrasts with crop residues 
or animal manures which turn over on a decadal timescale [7].

Soil physical and chemical characteristics have a direct effect on soil productivity for crop production [8]. Studies have showed that biochar application improved the physical, chemical, and biological properties and therefore crop yield. Biochar has been shown to improve soil structure [6], soil aggregate stability and porosity $[9,10]$, water-holding capacity and nutrient cycling [11, 12], tensile strength and penetration resistance [13], and soil infiltration and reduce runoff and decrease erosion [14]. It is also more stable than any other soil amendment and increases nutrient availability beyond a fertilizer effect [15]. Research results have also shown that biochar can ameliorate soil nutrient status, cation exchange capacity, nutrient use efficiency, and nutrient holding capacity and decrease soil acidity $[4,16,17]$.

Despite the results from previous studies on biochar, there are still scanty literature and data on the use of biochar for improving soil physical and chemical characteristics and crop yield and reducing soil loss especially on Alfisol of southwest Nigeria.

Cocoyam (Xanthosoma sagittifolium (L.) Schott) is an important tuber crop grown in many parts of the world, but a major staple food in Nigeria, South Pacific islands, and some part of Asia [18]. The corms and cormels are the major economic parts of cocoyam. Cocoyams are the cheapest and most handy source of carbohydrate in meals that are recommended for aged people, diabetics, convalescents, and most gastrointestinal disorder patients [19]. Moreso, Cocoyam, being a tuber crop, is sensitive to poor soil physical conditions [20] and potassium (K) in the soil [19]. Application of biochar could be a way of improving the physical and chemical soil condition and yield of cocoyam. Therefore, the objectives of this study were to determine the effects of biochar on soil physical and chemical properties, soil loss, and yield of cocoyam on a tropical Alfisol. In this experiment, we hypothesized that biochar will significantly (i) increase yield of cocoyam, (ii) improve soil physical and chemical properties, and (iii) reduce soil loss.

\section{Materials and Methods}

2.1. Experimental Site Treatments. Experiments were carried out at the Teaching and Research Farm, Rufus Giwa Polytechnic, Owo, Ondo State, Nigeria, in 2017 and 2018 seasons. The site lies between lat $7^{\circ} 12^{\prime} \mathrm{N}$ and long $5^{\circ} 35^{\prime} \mathrm{E}, 348 \mathrm{~m}$ above sea level, and is located in the forest-savanna transition zone of southwest Nigeria. The soil at Owo is an Alfisol classified as Oxic Tropludalf or Luvisol [21] derived from quartzite, gneiss, and schist [22]. The rainfall pattern is biomodal with peak in June and October. The total annual rainfall in the area is about $1350 \mathrm{~mm}$ while mean annual temperature is $32^{\circ} \mathrm{C}$. The site of the experiment was just recovered from a fallow of five years after arable cropping to crops such as yam, cassava, melon, and cowpea for about one year without organic or inorganic fertilizer application.

The experiment each year consisted of four levels of biochar applied at $0,10,20$, and $30 \mathrm{tha}^{-1}$. The four levels were laid out in a randomized complete block design
(RCBD) and replicated three times. The plot size was $5 \times 4 \mathrm{~m}$. Blocks were $3 \mathrm{~m}$ apart while plots were $1 \mathrm{~m}$ apart. The same exact position and layout of plots and treatments were used for the experiment in 2017 and 2018.

2.2. Land Preparation, Incorporation of Biochar, and Planting of Cocoyam. Biochar was obtained from a local producer of charcoal that uses hardwood in a traditional kilns to produce charcoal for domestic use [4]. The temperature inside the kiln was monitored with a thermocouple and had an average temperature of $500^{\circ} \mathrm{C}$ for 12 hours. The pyrolysed biochar was later grounded and sieved with $2 \mathrm{~mm}$ sieve and made ready for application.

After manual clearing of the site of all weeds, ploughing was done in April each year to the depth of $20 \mathrm{~cm}$. The site was layout to the required plot size of $5 \times 4 \mathrm{~m}$. The biochar was weighed and spread uniformly over the soil on plot basis to the required rates of $0,10,20$, and $30 \mathrm{tha}^{-1}$ which was equivalent to $0,20,40$, and $60 \mathrm{~kg} \mathrm{plot}^{-1}$, respectively. Incorporation was done to the depth of $10 \mathrm{~cm}$ with a traditional hoe each year. The biochar was allowed two weeks before planting cocoyam.

Cocoyam (Xanthosoma sagittifolium cv. Owo local) cormels weighing about $150 \mathrm{~g}$ were planted [20]. One cormel of cocoyam was planted per hill at a spacing of $1 \times 1 \mathrm{~m}$ to give a plant population of 20 plants per plot. Weeding was done manually at 45,70 , and 110 days after planting.

2.3. Determination of Soil Properties. In 2017 before the start of the experiment, soil samples from $0-0.15 \mathrm{~m}$ depth were randomly collected from 10 points from the experimental site. The soil samples were bulked together, air-dried, and sieved with $2 \mathrm{~mm}$ sieve for analysis (to serve as composite soil sample). The hydrometer was used for the determination of particle size [23]. Also, before the start of the experiment, bulk density of the experimental site was determined using the method of Campbell and Henshall [24]. Determination of soil chemical properties (SOM, N, $\mathrm{P}, \mathrm{K}, \mathrm{Ca}, \mathrm{Mg}$, and $\mathrm{CEC}$ ) was also carried out by the procedure that had been fully described elsewhere $[4,22]$. The air-dried soil samples that have passed through a $2 \mathrm{~mm}$ sieve were analysed for $\mathrm{pH}$ with $\mathrm{pH}$ meter and electrical conductivity (EC) with EC meter using $1: 2$ and $1: 5$ (soil: water) suspensions, respectively.

Two months after application of biochar, determination of selected soil physical properties on plots basis was started and was repeated on 2 other occasions in August and October each year. Core samplers $(0.04 \mathrm{~m}$ diameter and $0.15 \mathrm{~m}$ high) in each occasion were used to collect soil sample from $0-0.15 \mathrm{~m}$ depth at about $0.1 \mathrm{~m}$ away from cocoyam plant. The soil samples were used to evaluate bulk density and gravimetric moisture content after oven drying at $100^{\circ} \mathrm{C}$ for $24 \mathrm{~h}$. Soil porosity was calculated from the values of bulk density using the particle density value of $2.65 \mathrm{~g} \mathrm{~cm}^{-3}$.

Modified fast-wetting in water, as proposed by Bissonnais [25], was used to measure the aggregate stability of $2 \mathrm{~mm}$ air-dried aggregates $(35 \mathrm{~g})$. A $4 \mathrm{~cm}$ amplitude was applied for $5 \mathrm{~min}$ vertical movement to a nest of sieves 
(>2000, 1000-2000, 500-1000, 250-500, 250-106, <106 mm) immersed in a container of tap water $(101 \mathrm{mS} / \mathrm{cm})$. The material that remained after wet-shaking in each sieve was carefully removed, and the mean weight diameter (MWD) of the aggregate size was calculated using

$$
\mathrm{MWD}=\sum_{i=1}^{n} x_{i} w_{i}
$$

where $n$ is the number of sieves and $x$ and $w$ are diameter and weight, respectively.

Dispersion ratio was done by determining the amounts of silt and clay in calgon-dispersed as well as water-dispersed samples using the Bouyoucos hydrometer method of particle size analysis described in [23]. Dispersion ratio was determined as a measure of aggregate stability using the following formula:

$$
\text { dispersion ratio }=\frac{\left(\% \text { silt }+\operatorname{clay}\left(\mathrm{H}_{2} \mathrm{O}_{2}\right)\right)}{(\% \text { silt }+ \text { clay }(\text { calgon }))} \times 100 .
$$

Infiltration of water into the soil was determined in the experimental field using a double ring infiltrometer [26], with a $30 \mathrm{~cm}$ inner diameter and $60 \mathrm{~cm}$ outer diameter cylinder inserted $10 \mathrm{~cm}$ into the soil at the experimental plots. Water entering the soil was measured with a calibrated Marriott bottle. A constant water head of $20 \mathrm{~mm}$ was maintained in both rings [27].

At incorporation of biochar, five long (about $15 \mathrm{~cm}$ ) nails adapted from Anikwe et al. [28] were randomly driven into the topsoil of each experimental plot perpendicular to the soil surface, and its exposure with time was used to monitor soil loss or soil removal by erosion from each plot. The length of each nail exposed in each plot was measured using a string and meter rule.

At the end of each year, soil samples were also collected on each experimental plot and analysed for soil chemical properties.

2.4. Determination of Cocoyam Yield. Ten plants were selected per plot for determination of cocoyam yield. Harvesting was done 7 months after planting. The cormel yield was determined by harvesting 10 cocoyam plants per plot removing the cormels from the corms. They were washed and cleaned to remove traces of sand before weighing on a top loading balance to determine their fresh weights.

2.5. Chemical Analysis of Biochar Used for the Experiment. About $5 \mathrm{~g}$ of the biochar and poultry manure used were collected and analysed for $\mathrm{N}, \mathrm{P}, \mathrm{K}, \mathrm{Ca}$, and $\mathrm{Mg}$ as described by Tel and Hagarty [29]. N was determined by the microKjeldahl digestion method. The determination of $\mathrm{P}, \mathrm{K}, \mathrm{Ca}$, and $\mathrm{Mg}$ was done using the wet digestion method based on 25-5-5 mL of $\mathrm{HNO}_{3}-\mathrm{H}_{2} \mathrm{SO}_{4}-\mathrm{HClO}_{4}$ acids. Phosphorus was measured colorimetrically by the molybdate blue method in an autoanalyser, $\mathrm{K}$ was measured by flame photometry, and $\mathrm{Ca}$ and $\mathrm{Mg}$ were measured by an atomic absorption spectrophotometer. Biochar was analysed for EC using 1:20 (biochar: water) suspension as described in [30].
2.6. Statistical Analysis. Data collected from each experiment were subjected to mean separation analysis using a two-way ANOVA test at a significance of $p=0.05$. The differences between mean values were identified using Duncan's multiple range test. Pearson's correlation coefficients were calculated to determine how the soil properties are related.

\section{Results}

3.1. Characteristics of Experimental Soil and Biochar Used. The soil of the experimental site (Table 1) was sandy loam with high bulk density, acidic, and low in soil nutrient except $\mathrm{Mg}$ [31]. The biochar used was alkaline ( $\mathrm{pH}$ 7.6) in nature with high values of organic $\mathrm{C}, \mathrm{K}, \mathrm{Ca} \mathrm{Mg}, \mathrm{C}: \mathrm{N}$ ratio and porosity compared with the preplanting soil (Table 1 ).

3.2. Response of Soil Physical Properties to Biochar Application. The responses of soil physical properties to biochar application are shown in Table 2. Application of biochar in both years reduced bulk density and increased porosity of the soil significantly compared with the control. Biochar reduced bulk density and increased porosity as the levels of the biochar increased with $30 \mathrm{t} \mathrm{ha}^{-1}$ biochar having the least bulk density and highest porosity. In the first year, $30 \mathrm{t} \mathrm{ha}^{-1}$ biochar reduced bulk density by $46.3 \%$ and increased porosity by $46.5 \%$ compared with no application of biochar. The reduction in bulk density was $74.7 \%$ and increases in porosity were $65.0 \%$ in the second year. Application of biochar at 10,20 , and $30 \mathrm{t} \mathrm{ha}^{-1}$ reduced bulk density and increased porosity by $4.3,8.3$, and $18.7 \%$, respectively, in the second year compared with the first year. The interaction between year $(Y)$ and biochar $(B)(Y \times B)$ for both bulk density and porosity was significant.

Soil moisture content, MWD, and infiltration rate increased significantly (Table 2) with the application of biochar compared with no application (control). These parameters significantly increased with the level of biochar. Year also increased moisture content, MWD, and infiltration rate significantly with 2018 having higher values. The interaction of $Y \times B$ was significant for moisture content, MWD, and infiltration rate.

Application of biochar reduced soil loss compared with the control. The highest soil loss (355.5 and 365.1 in 2017 and 2018 , respectively) occurred in the control, and the lowest soil loss (118.0 and 68.25 in 2017 and 2018, respectively) occurred in the amended plots with the highest application rate $30 \mathrm{tha}^{-1}$ biochar. Soil loss was significantly reduced as the level of biochar increased. Using the mean of the two years, biochar at $30 \mathrm{t} \mathrm{ha}^{-1}$ reduced soil loss by $286.9 \%$ compared with the control. Second year (2018) significantly reduced soil loss compared with first year (2017). When 2018 is compared with 2017 in terms of soil loss, in the amended plots, 2018 reduced soil loss by 7.4, 20, and 73.5\%, respectively, for 10,20 , and $30 \mathrm{t} \mathrm{ha}^{-1}$ biochar, whereas there was an increase of $2.7 \%$ soil loss in the control plot in 2018 compared with 2017 . The interaction $Y \times B$ was significant for soil loss. 
TABLe 1: Properties of the experimental site and biochar prior to experimentation in 2017.

\begin{tabular}{lcc}
\hline Properties & Soil & Biochar \\
\hline Sand (\%) & $68.1 \pm 1.3$ & NA \\
Silt (\%) & $16.2 \pm 1.2$ & NA \\
Clay (\%) & $15.7 \pm 1.1$ & NA \\
Textural class & Nandy loam & $0.60 \pm 0.03$ \\
Bulk density $\left(\mathrm{Mg} \mathrm{m}^{-3}\right)$ & $1.57 \pm 0.04$ & $77.35 \pm 1.5$ \\
Porosity (\%) & $40.75 \pm 1.4$ & $52 \pm 1.2$ \\
Organic carbon (\%) & $1.17 \pm 0.03$ & $0.65 \pm 0.02$ \\
Total N (\%) & $0.18 \pm 0.01$ & 80 \\
C:N ratio & 6.5 & NA \\
Ash (\%) & $11.1 \pm 0.3$ & $0.49 \pm 0.01$ \\
Available P (mg kg-1) & $0.10 \pm 0.01$ & $0.36 \pm 0.01$ \\
Exchangeable K (cmol kg & \\
Exchangeable Ca $\left(\mathrm{cmol} \mathrm{kg}^{-1}\right)$ & $2.72 \pm 0.03$ & $1.75 \pm 0.02$ \\
Exchangeable Mg $\left(\mathrm{cmol} \mathrm{kg}^{-1}\right)$ & $0.42 \pm 0.01$ & $4.51 \pm 0.1$ \\
pH (water) & $5.69 \pm 0.04$ & $7.75 \pm 0.1$ \\
Electrical conductivity $\left(\mathrm{dS} \mathrm{m}^{-1}\right)$ & $0.11 \pm 0.01$ & $7.61 \pm 0.05$ \\
\hline
\end{tabular}

TABLE 2: Effect of biochar on some selected soil physical properties in 2017 and 2018.

\begin{tabular}{|c|c|c|c|c|c|c|c|c|c|}
\hline Year & $\begin{array}{l}\text { Biochar rate } \\
\left(\mathrm{t} \mathrm{ha}^{-1}\right)\end{array}$ & $\begin{array}{c}\text { Bulk density } \\
\left(\mathrm{Mg} \mathrm{m}^{-3}\right)\end{array}$ & $\begin{array}{c}\text { Porosity } \\
(\%)\end{array}$ & $\begin{array}{c}\text { Moisture } \\
\text { content }(\%)\end{array}$ & $\begin{array}{l}\text { MWD } \\
(\mathrm{mm})\end{array}$ & $\begin{array}{l}\mathrm{DR} \\
(\%) \\
\end{array}$ & $\operatorname{IR}\left(\mathrm{cm} \mathrm{hr}^{-1}\right)$ & $\begin{array}{c}\text { Soil loss } \\
(\mathrm{cm})\end{array}$ & Soil loss $\left(\mathrm{kg} \mathrm{ha}^{-1}\right)$ \\
\hline \multirow{4}{*}{2017} & 0 & $1.58 \mathrm{a}$ & $40.4 \mathrm{~d}$ & $9.6 \mathrm{~d}$ & $1.06 \mathrm{~d}$ & $71 \mathrm{a}$ & $10.6 \mathrm{~d}$ & $2.25 \mathrm{a}$ & $355.5 a$ \\
\hline & 10 & $1.44 \mathrm{~b}$ & $45.7 \mathrm{c}$ & $11.2 \mathrm{c}$ & $1.41 \mathrm{c}$ & $65 b$ & $17.7 \mathrm{c}$ & $1.75 b$ & $252.0 \mathrm{~b}$ \\
\hline & 20 & $1.30 \mathrm{c}$ & $50.9 \mathrm{~b}$ & $13.1 \mathrm{~b}$ & $1.61 \mathrm{~b}$ & $60 c$ & $21.4 \mathrm{~b}$ & $1.20 \mathrm{c}$ & $156.0 \mathrm{c}$ \\
\hline & 30 & $1.08 \mathrm{~d}$ & $59.2 \mathrm{a}$ & $14.9 \mathrm{a}$ & $1.82 \mathrm{a}$ & $55 \mathrm{~d}$ & $24.1 \mathrm{a}$ & $1.10 \mathrm{~d}$ & $118.0 \mathrm{~d}$ \\
\hline \multirow{4}{*}{2018} & 0 & $1.59 \mathrm{a}$ & $40.0 \mathrm{~d}$ & $10.1 \mathrm{~d}$ & $1.05 \mathrm{~d}$ & $72 \mathrm{a}$ & $10.1 \mathrm{~d}$ & $2.29 \mathrm{a}$ & $365.1 \mathrm{a}$ \\
\hline & 10 & $1.38 \mathrm{~b}$ & $47.9 c$ & $12.6 \mathrm{c}$ & $1.55 \mathrm{c}$ & $61 b$ & $18.2 \mathrm{c}$ & $1.70 \mathrm{~b}$ & $234.6 \mathrm{~b}$ \\
\hline & 20 & $1.20 \mathrm{c}$ & $54.7 \mathrm{~b}$ & $14.6 \mathrm{~b}$ & $1.71 \mathrm{~b}$ & $56 c$ & $23.4 \mathrm{~b}$ & $1.09 \mathrm{c}$ & $130.8 \mathrm{c}$ \\
\hline & 30 & $0.91 d$ & $66.0 \mathrm{a}$ & $15.9 \mathrm{a}$ & $1.95 \mathrm{a}$ & $48 \mathrm{~d}$ & $27.7 \mathrm{a}$ & $0.75 \mathrm{~d}$ & $68.25 \mathrm{~d}$ \\
\hline Year $(Y)$ & * & $*$ & $*$ & $*$ & $*$ & $*$ & $*$ & $*$ & $*$ \\
\hline Biochar $(B)$ & $*$ & * & * & $*$ & * & $*$ & $*$ & $*$ & $*$ \\
\hline$Y \times B$ & $*$ & $*$ & $*$ & $*$ & $*$ & * & $*$ & $*$ & $*$ \\
\hline
\end{tabular}

Values followed by similar letters under the same column are not significantly different at $p=0.05$ according to Duncan's multiple range test; MWD $=$ mean weight diameter of soil aggregate; $\mathrm{DR}=$ dispersion ratio; $\mathrm{IR}=$ infiltration rate.

3.3. Response of Soil Chemical Properties to Biochar Application. Application of biochar increased soil chemical properties in the amended plots relative to the control in both years (Table 3), except pH and $\mathrm{N}$ in 2017. Also, in both years (except the case of no significant differences between 10 and $20 \mathrm{tha}^{-1}$ biochar levels for $\mathrm{N}$, $\mathrm{P}, \mathrm{K}$, and $\mathrm{Mg}$ in 2017), biochar increased soil OM, N, P, K, $\mathrm{Ca}, \mathrm{Mg}$, and CEC from $0-30 \mathrm{t} \mathrm{ha}^{-1}$. There were no significant differences in the $\mathrm{pH}$ values between 20 and $30 \mathrm{t}$ $\mathrm{ha}^{-1}$ biochar. The values of SOM, N, P, K, Ca, Mg, and CEC in 2018 were significantly higher than those of 2017. The interactive effect $Y \times B$ was significant for all soil chemical properties except $\mathrm{pH}$.

3.4. Response of Cocoyam Yield to Biochar. Application of biochar increased the cormel yield of cocoyam significantly compared with the control (Figure 1). In both years, the yield of cocoyam was increased as the level of biochar increased from $0-30 \mathrm{t} \mathrm{ha}^{-1}$, and year 2018 increased yield of cocoyam compared with 2017. Compared with 2017, there was an increase in cocoyam yield by $8.1,7.8$, and $5.5 \%$ for 10,20 , and $30 \mathrm{tha}^{-1}$ biochar, respectively, and a reduction of $13 \%$ for the control. The interaction between $Y \times B$ was significant for cocoyam yield.

\section{Discussion}

The soil of the site of the experiment was low in nutrient, acidic, and fairly high in bulk density. These states of the soil are the characteristics of tropical soils [32, 33]. The fairly high bulk density of the site was partly related to its low organic matter content [34]. The reduced bulk density and increased porosity of the soil as a result of the application of biochar were due to the relatively lower bulk density of biochar relative to that of the soil. Also, biochar has high porosity (Table 1) which results from retaining the cell wall structure of the biomass feedstock [35]. Therefore, being a porous material when added to the soil, it increases its porosity and thus reduced bulk density $[4,36]$. Hseu et al. [37] reported that the change in porosity with biochartreated soils was as a result of formation of macropores and rearrangement of soil particle. Laird et al. [38] also reported similar finding and suggested that biochar is acting as a soil conditioner. The increase in porosity and decrease in bulk density as the level of biochar increased from $0-30 \mathrm{t} \mathrm{ha}^{-1}$ can 
TABLE 3: Effect of biochar on soil chemical properties in 2017 and 2018.

\begin{tabular}{|c|c|c|c|c|c|c|c|c|c|}
\hline Year & $\begin{array}{l}\text { Biochar } \\
\text { rate }\end{array}$ & $\begin{array}{c}\mathrm{pH} \\
\text { (water) }\end{array}$ & $\begin{array}{l}\mathrm{OM} \\
(\%)\end{array}$ & N (\%) & $\mathrm{P}\left(\mathrm{mg} \mathrm{kg}^{-1}\right)$ & $\mathrm{K}\left(\mathrm{cmol} \mathrm{kg}^{-1}\right)$ & $\begin{array}{c}\mathrm{Ca} \\
\left.\left(\mathrm{cmol} \mathrm{kg}^{-1}\right)\right)\end{array}$ & $\begin{array}{c}\mathrm{Mg} \\
\left.\left(\mathrm{cmol} \mathrm{kg}^{-1}\right)\right)\end{array}$ & $\begin{array}{c}\text { CEC } \\
\left.\left(\mathrm{cmol} \mathrm{kg}^{-1}\right)\right)\end{array}$ \\
\hline \multirow{4}{*}{2017} & 0 & $5.61 \mathrm{c}$ & $1.78 \mathrm{~d}$ & $0.16 \mathrm{~b}$ & $8.6 c$ & $0.09 c$ & $1.69 d$ & $0.35 c$ & $1.1 \mathrm{~d}$ \\
\hline & 10 & $5.72 b c$ & $2.52 \mathrm{c}$ & $0.17 \mathrm{ab}$ & $10.1 \mathrm{~b}$ & $0.12 b$ & $1.72 \mathrm{c}$ & $0.38 \mathrm{~b}$ & $3.4 c$ \\
\hline & 20 & $5.88 \mathrm{ab}$ & $2.75 b$ & $0.17 \mathrm{ab}$ & $10.7 b$ & $0.13 \mathrm{ab}$ & $1.92 \mathrm{~b}$ & $0.39 \mathrm{~b}$ & $5.3 b$ \\
\hline & 30 & $5.96 \mathrm{a}$ & $2.97 \mathrm{a}$ & $0.18 \mathrm{a}$ & $14.6 \mathrm{a}$ & $0.14 \mathrm{a}$ & $2.45 a$ & $0.44 \mathrm{a}$ & $7.5 \mathrm{a}$ \\
\hline \multirow{4}{*}{2018} & 0 & $5.60 \mathrm{~d}$ & $1.70 \mathrm{~d}$ & $0.15 \mathrm{~d}$ & $7.1 \mathrm{~d}$ & $0.07 \mathrm{~d}$ & $1.61 \mathrm{~d}$ & $0.33 d$ & $1.0 \mathrm{~d}$ \\
\hline & 10 & $5.83 \mathrm{bc}$ & $2.70 c$ & $0.18 \mathrm{c}$ & $12.6 c$ & $0.13 c$ & $1.84 \mathrm{c}$ & $0.43 c$ & $5.6 c$ \\
\hline & 20 & $6.10 \mathrm{ab}$ & $2.89 \mathrm{~b}$ & $0.19 b c$ & $14.8 \mathrm{~b}$ & $0.15 b$ & $2.30 \mathrm{~b}$ & $0.56 b$ & $8.5 b$ \\
\hline & 30 & $6.31 \mathrm{a}$ & $3.18 \mathrm{a}$ & $0.21 \mathrm{a}$ & $17.7 \mathrm{a}$ & $0.17 \mathrm{a}$ & $2.79 \mathrm{a}$ & $0.67 \mathrm{a}$ & $12.9 \mathrm{a}$ \\
\hline Year $(Y)$ & & ns & $*$ & $*$ & $*$ & $*$ & $*$ & $*$ & $*$ \\
\hline Biochar $(B)$ & & $*$ & $*$ & * & $*$ & * & $*$ & $*$ & * \\
\hline$Y \times B$ & & ns & $*$ & $*$ & $*$ & $*$ & $*$ & $*$ & $*$ \\
\hline
\end{tabular}

Values followed by similar letters under the same column are not significantly different at $p=0.05$ according to Duncan's multiple range test, ${ }^{*}=$ significant at $5 \%$ level of probability; ns = not significant at $5 \%$ probability level.

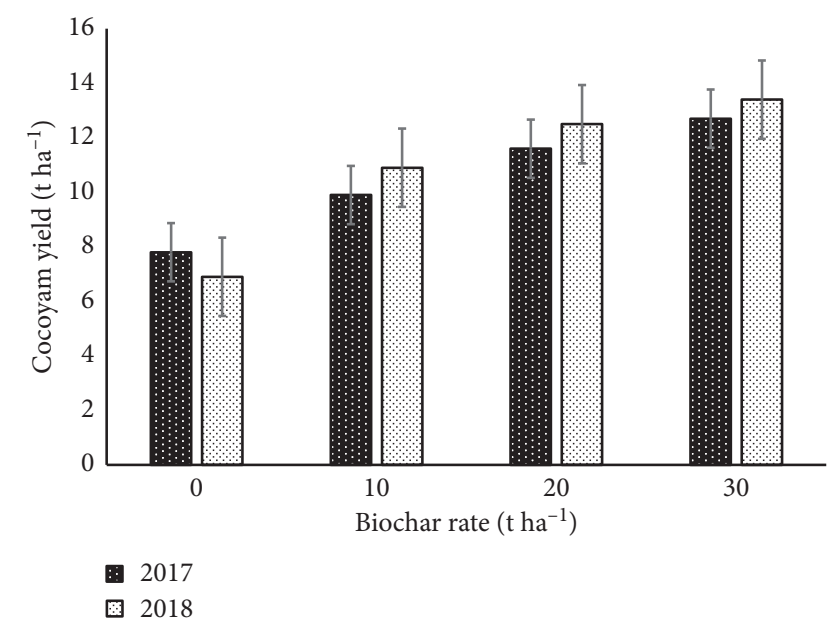

Figure 1: Effects of different rates of biochar on cocoyam yield in 2017 and 2018; vertical bars show standard errors.

be adduced to greater effects of biochar on porosity from each level of biochar application. This is in agreement with Kätterer et al.'s study [39] in Kenya where biochar addition increased soil porosity and water holding capacity after continuous addition for 10 years compared with bared soil. These results are also in agreement with those of Ndor et al. [40] where the applications of rice husk and sawdust biochars had a significant effect on soil moisture content, bulk density, porosity, and soil water-filled pore space.

In a 3-year field study [41], it was reported that biochar application reduced soil bulk density of $0-7.5 \mathrm{~cm}$ soil layer by 4.5 and $6.0 \%$ for $0.23 \mathrm{~kg} \mathrm{~m}^{-2}$ and $0.45 \mathrm{~kg} \mathrm{~m}^{-2}$ application rate, respectively.

Application of biochar increased moisture content of the soil compared with the control. This could be adduced to biochar soils having more micropores to physically retain water and or improved aggregation that resulted in creating more pore spaces as a result of greater earthworm burrowing. Another reason for the differences in water content between biochar-treated plots and the control could probably also be due to the differences in bulk density between treatments. The bulk density of the control plots was higher (reducing the spaces where water could be retained) compared with the bulk density of the biochar-treated plots [4]. Chan et al. [42] also reported that the water retention ability of biochar could be as a result of increase in overall net soil surface area in soil after biochar application. A long-term column study indicated that biochar amended Clarion soil retained up to $15 \%$ more water, and $13 \%$ and $10 \%$ more water retention at $-100 \mathrm{kPa}$ and $-500 \mathrm{kPa}$ soil matric potential respectively, compared with control [38]. The increase in moisture content with rates of biochar was adduced to increase in surface area for absorbing more moisture as the rates of biochar increase.

MWD increased significantly in biochar-amended soil compared with the control. MWD indicates prevalence of larger and more stable aggregates and therefore is an index of soil aggregate stability and quality [43, 44]. The increased MWD for plots with biochar could be due to increase in binding organic substances from the biochar, thereby improving the interparticular aggregate cohesion among the soil particles $[45,46]$. Organic amendment has been known to enhance soil aggregate formation and stability [47]. The increase in soil aggregate stability following biochar application could be due to high carbon (C) associated with biochar [48]. The $\mathrm{C}$ molecules form bonds with the oxides, and the organic matter (OM) serves as food for soil microorganism making the environment favourable for them. The substrates supplied to the microorganisms by the labile $\mathrm{OM}$ on the surface of biochar enhance the excretion of mucilage by microorganism, which in turn builds stable soil aggregate [38]. There was a significant $Y \times B$ interaction for MWD; this can be related to increased organic $C$ from the biochar which is an important binding agent in the formation and stability of soil aggregates $[49,50] . Y \times B$ interaction could also be related to the active functional groups of biochar particles which may form complexes over time to make up soil aggregates [51].

Biochar-applied plots reduced dispersion ratio compared with the control. This was adduced to the OM from the biochar applied to soil. The biochar applied stabilized the soil structure and reduced dispersion ratio since organic matter addition is essential for stabilizing soil against physical degradation and soil erosion. Soils with high dispersion ratio are weak structurally and can easily be eroded [27]. 
The downward movement of water into the soil is known as infiltration. Biochar-applied plots increased infiltration rate compared with the control. This could be as a result of more pores created in the soil matrix as a result of biochar application because biochar is very porous. Prober et al. [52] reported an increase in water infiltration after a 2-year experiment in which biochar was applied at a rate of $20 \mathrm{Mg} \mathrm{ha}^{-1}$ to a clay loam soil.

The reduction in soil loss in the biochar plots compared with the control was adduced to increased aggregation which might have increased infiltration rate and therefore reduce runoff. Table 4 shows that soil loss in this experiment was dependent among other factors: bulk density, porosity, moisture content, MWD, dispersion ratio, infiltration rate, and SOC. Application of biochar would have increased SOM which would have stabilized soil structure by increasing MWD, porosity, moisture content, and infiltration rate and reducing dispersion ratio and bulk density. Soils with high dispersion rate are weak structurally and can easily be eroded. Many researchers have used this index in predicting soil erosion by water [53]. Other researchers $[6,54]$ also showed that addition of biochar will increase SOM and therefore reduce soil loss by increasing the size of the soil aggregates as well as stabilizing soil aggregates. The reduced soil loss with increased rate of biochar was due to increased OM, better stabilization, and improved physical properties of the soil with the biochar rates. The improved soil physical properties and SOC in the second year were adduced to residual effect of biochar from the first season and subsequent application in the second year. This present result is in agreement with that of Agbede et al. [55] where incorporating biochar into the soil significantly reduced soil loss by $31 \%, 58 \%$, and $82 \%$ at 10,20 , and $30 \mathrm{t} \mathrm{ha}^{-1}$ application rates, respectively, compared with the control on tropical Alfisol at Owo, southwest Nigeria.

Biochar improved soil chemical properties because of its ability to absorb soluble organic matter and inorganic nutrients [56]. Lehmann and Rondon [16] reported that biochar can adsorb both $\mathrm{NH}_{4}{ }^{+}$and $\mathrm{NH}_{3}{ }^{-}$from the soil solution. Biochar is very efficient at adsorbing dissolved solute nutrients such as ammonium [57], nitrate [58], phosphate [59], and other ionic solutes [60]. Biochar as reported by Jia et al. [61] can absorb leachate which can help to absorb organic matter, total soluble $\mathrm{N}$, plant available $\mathrm{P}$, and $\mathrm{K}$, thereby increasing the nutrient retention capacity of the soil. The increase in $\mathrm{K}, \mathrm{Ca}, \mathrm{Mg}$, and CEC in biochar-applied soils was due $[62,63]$ to the presence of cation exchange sites on the surface of biochar. Another reason for the high amount of cations in biochar soil may be due to the presence of carboxyl group in biochar which is indicated by high oxygen and carbon ratios on the surface of the biochar after microbial degradation [10,64]. Soil chemical properties in 2018 were improved compared with 2017; this was due to the fact that biochar increased plant nutrient availability with age in the soil due to residual effect. The improved soil nutrients in 2018 compared with 2017 could also be as a result of the addition of new (fresh) biochar in 2018 which might induce net immobilization of inorganic $\mathrm{N}$ in already present in soil solution [65]. The increase in $\mathrm{pH}$ with biochar was due to the fact that biochar contains ash. These results of soil chemical properties with biochar are in agreement with the work of Njoku et al. [66] in which rice husk and sawdust biochar rates had a significant effect on all the chemical properties in the soil. $10 \mathrm{t} \mathrm{ha}^{-1}$ (the highest biochar rate) of rice husk and sawdust biochar produced the highest levels of $\mathrm{pH}, \mathrm{N}, \mathrm{K}, \mathrm{OC}, \mathrm{Mg}, \mathrm{Na}$, and CEC. This present result on soil chemical properties with biochar is also in agreement with that of Oguntunde et al. [67] in Ejura, Ghana, where there was a significant increase in soil $\mathrm{pH}$, base saturation, exchangeable $\mathrm{Ca}, \mathrm{Mg}, \mathrm{K}$, and $\mathrm{Na}$, and available $\mathrm{P}$ in biochar-applied soils compared to the adjacent soils and that of Alling et al. [68] on tropical soils from Zambia and Indonesia where biochar has the ability to release essential plant growth nutrients as well as alleviate Al toxicity in those soils.

The increased yield of cocoyam in this study was due to improved physical and chemical characteristics of the soil as a result of biochar application. The improved soil physical properties favours reduced bulk density and increased porosity which would have enhanced better root penetration for nutrient absorption and also enhanced better tuberization of cocoyam cormels. Adekiya et al. [20] reported that cocoyam cormels are sensitive to high bulk density. Also, the enhanced availability of nutrient supply due to biochar in addition to soil physical properties also aided the yield of cocoyam. The increase in cations in biochar-amended plots brings an improvement in soil fertility and its nutrient retention [69] especially $\mathrm{K}$ that is important for tuber formation of cocoyam [19]. Adekiya et al. [4] reported that biochar alone because of its inert nature did not increase the yield of a short season crop like radish (Raphanus sativus L.) significantly in the first year of application; however, for cocoyam in this current study it did. This was due to the long period of growth of cocoyam ( 9 months) by which the biochar applied would have fully been oxidized and beneficial to the cocoyam. Singh et al. [70] reported that biochar develops reactive surfaces with time after exposure to water and oxygen in the soil. Major et al. [71] reported that the beneficial effect of applying biochar to soil improves with time. These improved soil chemical properties in the second year explain the yield differences of cocoyam between 2017 and 2018. The increase in cocoyam yield in this study agreed with Jeffery et al [73] that application of biochar may especially benefit crop production in low-nutrient, acidic soils in the tropics. This is in agreement with the result of Kätterer et al. [39] in Kenya where application of biochar had led to increases in the yields of maize and soya bean. Also, the result is in agreement with that of Njoku et al. [66] where application of sawdust and rice husk biochars at their highest rate of $10 \mathrm{t} \mathrm{ha}^{-1}$ produced the highest seed weight of sesame (Sesamum indicum L.) in Lafia, Nasarawa State, Nigeria. Reichenauer et al. [73] observed that the application of biochar, even at a very low dosage, would impact crop yield positively. Other crops such as maize [74], soybean [75], and upland rice [14] have been reported to increase in yield with application of biochar. 
TABLE 4: Correlation coefficient between soil properties.

\begin{tabular}{|c|c|c|c|c|c|c|c|c|}
\hline & Bulk density & Porosity & Moisture content & MWD & DR & IR & Soil loss & SOM \\
\hline Bulk density & 1 & & & & & & & \\
\hline Porosity & $-1.000^{* *}$ & 1 & & & & & & \\
\hline Moisture content & $-0.975^{* *}$ & $0.973^{* *}$ & 1 & & & & & \\
\hline MWD & $-0.959^{* *}$ & $0.957^{* *}$ & $0.983^{* *}$ & 1 & & & & \\
\hline DR & $0.985^{* *}$ & $-0.984^{* *}$ & $-0.984^{* *}$ & $-0.985^{* *}$ & 1 & & & \\
\hline IR & $-0.963^{* *}$ & $0.961^{* *}$ & $0.974^{* *}$ & $0.993^{* *}$ & $-0.983^{* *}$ & 1 & & \\
\hline Soil loss & $0.958^{* *}$ & $-0.956^{* *}$ & $-0.972^{* *}$ & $-0.979^{* *}$ & $0.973^{* *}$ & $-0.991^{* *}$ & 1 & \\
\hline SOM & $-0.837^{* *}$ & $0.834^{*}$ & $0.865^{* *}$ & $0.937^{* *}$ & $-0.897^{* *}$ & $0.931^{* *}$ & $-0.902^{* *}$ & 1 \\
\hline
\end{tabular}

${ }^{*}$ Significant difference at $p=0.05 ;{ }^{* *}$ significant difference at $p=0.01 ; \mathrm{MWD}=$ mean weight diameter of soil aggregate; $\mathrm{DR}=$ dispersion ratio; $\mathrm{IR}=$ infiltration rate.

\section{Conclusion}

Field experimental results showed that biochar made from hardwood at a temperature of $500^{\circ} \mathrm{C}$ for 12 hours can be used to improve the yield of cocoyam and soil physical (bulk density, porosity, moisture content, mean weight diameter (MWD) of soil aggregates, dispersion ratio, and infiltration rate) and chemical (SOM, N, P, K, Ca, Mg, and CEC) properties and erosion resistance. These results suggest that the addition of wood biochar effectively improved poor soil characteristics in severely degraded sandy loam Alfisol and also reduced soil losses. The increased yield of cocoyam was due to improved soil physical and chemical properties. Therefore, biochar could be used to reduce rapid soil loss, improve soil quality, and increase cocoyam yield in tropical regions.

\section{Data Availability}

All data used to support the findings of this study are included within the article.

\section{Conflicts of Interest}

The authors declare that there are no conflicts of interest.

\section{References}

[1] R. Lal, "Long-term tillage and maize monoculture effects on a tropical alfisol in western Nigeria. I. crop yield and soil physical properties," Soil and Tillage Research, vol. 42, no. 3, pp. 145-160, 1997.

[2] R. Lal, Sustainable Management of Soil Resources in the Humid Tropics, United Nations University Press, New York, NY, USA, 1995.

[3] S. Ehui and J. Pender, "Resource degradation, low agricultural productivity, and poverty in sub-Saharan Africa: pathways out of the spiral," Agricultural Economics, vol. 32, no. 1, pp. 225-242, 2005.

[4] A. O. Adekiya, T. M. Agbede, C. M. Aboyeji, O. Dunsin, and V. T. Simeon, "Effects of biochar and poultry manure on soil characteristics and the yield of radish," Scientia Horticulturae, vol. 243, pp. 457-463, 2019.

[5] W. J. Busscher, J. M. Novak, and M. Ahmedna, "Physical effects of organic matter amendment of a southeastern US coastal loamy sand," Soil Science, vol. 176, no. 120, pp. 661-667, 2011.
[6] S.-H. Jien and C.-S. Wang, "Effects of biochar on soil properties and erosion potential in a highly weathered soil," Catena, vol. 110, pp. 225-233, 2013.

[7] S. Bruun, E. S. Jensen, and L. S. Jensen, "Microbial mineralization and assimilation of black carbon: dependency on degree of thermal alteration," Organic Geochemistry, vol. 39, no. 7, pp. 839-845, 2008.

[8] J. G. Benjamin, D. C. Nielsen, and M. F. Vigil, "Quantifying effects of soil conditions on plant growth and crop production," Geoderma, vol. 116, no. 1-2, pp. 137-148, 2003.

[9] J. M. Kimetu and J. Lehmann, "Stability and stabilisation of biochar and green manure in soil with different organic carbon contents," Australian Journal of Soil Research, vol. 48, no. 6-7, pp. 577-585, 2010.

[10] B. Liang, J. Lehmann, D. Solomon et al., "Black carbon increases cation exchange capacity in soils," Soil Science Society of America Journal, vol. 70, no. 5, pp. 1719-1730, 2006.

[11] O. R. Harvey, L.-J. Kuo, A. R. Zimmerman, P. Louchouarn, J. E. Amonette, and B. E. Herbert, "An index-based approach to assessing recalcitrance and soil carbon sequestration potential of engineered black carbons (biochars)," Environmental Science \& Technology, vol. 46, no. 3, pp. 1415-1421, 2012.

[12] S. D. Joseph, M. Camps-Arbestain, Y. Lin et al., "An investigation into the reactions of biochar in soil," Soil Research, vol. 48, no. 7, pp. 501-515, 2010.

[13] K. Y. Chan, L. Van Zwieten, I. Meszaros, A. Downie, and S. Joseph, "Agronomic values of greenwaste biochar as a soil amendment," Australian Journal of Soil Research, vol. 45, no. 8, pp. 629-634, 2007.

[14] H. Asai, B. K. Samson, H. M. Stephan et al., "Biochar amendment techniques for upland rice production in northern laos 1 soil physical properties, leaf SPAD and grain yield," Field Crops Research, vol. 111, no. 1-2, pp. 81-84, 2009.

[15] J. Lehmann, C. Czimczik, C. Laird, and S. Sohi, "Stability of biochar in soil," in Biochar for Environmental Management: Science and Technology, J. Lehmann and S. Josep, Eds., Earthscan, London, UK, 2009.

[16] J. Lehmann and M. Rondon, "Biochar soil management on highly weathered soils in the humid tropics," in Biological Approaches to Sustainable Soil Systems, N. Uphoff, A. S. Ball, E. Fernandes et al., Eds., pp. 517-530, CRC Press, Boca Raton, FA, UK, 2006.

[17] A. E. Ajayi, D. Holthusen, and R. Horn, "Changes in microstructural behaviour and hydraulic functions of biochar amended soils," Soil and Tillage Research, vol. 155, pp. 166$175,2016$.

[18] D. F. Uwah, A. U. Udoh, and G. A. Iwo, "Effect of organic and mineral fertilizers on growth and yield of cocoyam (Colocasia 
esculenta (L.) Schott)," International Journal of Agriculture Sciences, vol. 3, no. 1, pp. 33-38, 2011.

[19] A. O. Adekiya, T. M. Agbede, and S. O. Ojeniyi, "The effect of three years of tillage and poultry manure application on soil and plant nutrient composition, growth and yield of cocoyam," Experimental Agriculture, vol. 52, no. 3, pp. 466-476, 2016.

[20] A. O. Adekiya, S. O. Ojeniyi, and T. M. Agbede, "Soil physical and chemical properties and cocoyam yield under different tillage systems in tropical Alfisol," Experimental Agriculture, vol. 47 , no. 3, pp. 477-488, 2011.

[21] Soil Survey Staff, "Keys to soil taxonomy," Agricultural Handbook No. 436, USDA-NRCS, Washington, DC, USA, 11th edition, 2010.

[22] A. O. Adekiya, "Legume mulch materials and poultry manure affect soil properties, and growth and fruit yield of tomato," Agriculturae Conspectus Scientificus, vol. 83, no. 2, pp. 161167, 2018.

[23] G. W. Gee and D. Or, "Particle-size analysis," in Methods of Soil Analysis. Part 4. Physical Methods, J. H. Dane and G. C. Topp, Eds., pp. 255-294, SSSA, Inc., Madison, WI, USA, 2002.

[24] D. J. Campbell and J. K. Henshall, "Bulk density," in Physical Methods of Soil Analysis, K. A. Smith and C. E. Mullin, Eds., pp. 329-366, Marcel Dekker, New York, NY, USA, 1991.

[25] Y. Bissonnais, "Aggregate stability and assessment of soil crustability and erodibility: I. theory and methodology," European Journal of Soil Science, vol. 47, no. 4, pp. 425-437, 1996.

[26] H. Bouwer, "Intake rate. cylinder infiltrometer," in Methods of Soil Analysis, ASA Monograph 9, A. Klute, Ed., pp. 825-843, ASA, Madison, WI, USA, 1986.

[27] A. O. Adekiya, S. O. Ojeniyi, and O. E. Owonifari, "Effect of cow dung on soil physical properties, growth and yield of maize (Zea mays) in a tropical Alfisol," Scienta Agricultuae, vol. 15, no. 2, pp. 374-379, 2016.

[28] M. A. N. Anikwe, O. E. Ngwu, C. N. Mbah, C. E. Onoh, and E. E. Ude, "Effect of ground cover by different crops on soil loss and physiochemical properties of an ultisol in south eastern Nigeria," Nigerian Journal of Soil Science, vol. 17, pp. 94-97, 2007.

[29] D. A. Tel and M. Hagarty, Soil and Plant Analysis. Study Guide for Agricultural Laboratory Directors and Technologists Working in Tropical Regions. Ibadan (Nigeria): International Institute of Tropical Agriculture (IITA) in Conjunction with the University of Guelph, University of Guelph, Guelph, Canada, 1984.

[30] S. Rajkovich, A. Enders, K. Hanley, C. Hyland, A. R. Zimmerman, and J. Lehmann, "Corn growth and nitrogen nutrition after additions of biochars with varying properties to a temperate soil," Biology and Fertility of Soils, vol. 48, no. 3, pp. 271-284, 2012.

[31] E. A. Akinrinde and G. O. Obigbesan, "Evaluation of the fertility status of selected soils for crop production in five ecological zones of Nigeria," in Proceedings of the 26th Annual Conference of Soil Science Society of Nigeria, pp. 279-288, SSSN, Ibadan, Nigeria, 2000.

[32] R. Lal, "Soil surface management in the tropics for intensive land use and high and sustainable production," Advances in Soil Science, Springer, vol. 5, pp. 1-109, Berlin, Germany, 1986.

[33] N. de Ridder and H. van Keulen, "Some aspects of the role of organic matter in sustainable intensified arable farming systems in West-African semi-arid-tropics (SAT)," Fertilizer Research, vol. 26, no. 1-3, pp. 299-310, 1990.

[34] A. O. Adekiya and S. O. Ojeniyi, "Evaluation of tomato growth and soil properties under methods of seedling bed preparation in an Alfisol in the rainforest zone of southwest Nigeria," Soil and Tillage Research, vol. 64, no. 3-4, pp. 275-279, 2002.

[35] N. K. Yadav, V. Kumar, K. R. Sharma et al., "Biochar and their impacts on soil properties and crop productivity: a review," Journal of Pharmacognosy and Phytochemistry, vol. 7, no. 4, pp. 49-54, 2018.

[36] P. Nyambo, T. Taeni, C. Chiduza, and T. Araya, "Effects of maize residue biochar amendments on soil properties and soil loss on acidic hutton soil," Agronomy, vol. 8, no. 11, p. 256, 2018.

[37] Z.-Y. Hseu, S.-H. Jien, W.-H. Chien, and R.-C. Liou, "Impacts of biochar on physical properties and erosion potential of a mudstone slopeland soil," The Scientific World Journal, vol. 2014, Article ID 602197, 10 pages, 2014.

[38] D. A. Laird, P. Fleming, D. D. Davis, R. Horton, B. Wang, and D. L. Karlen, "Impact of biochar amendments on the quality of a typical Midwestern agricultural soil," Geoderma, vol. 158, no. 3-4, pp. 443-449, 2010.

[39] T. Kätterer, D. Roobroeck, O. Andrén et al., "Biochar addition persistently increased soil fertility and yields in maize-soybean rotations over 10 years in sub-humid regions of Kenya," Field Crops Research, vol. 235, pp. 18-26, 2019.

[40] E. Ndor, O. Jayeoba, and C. Asadu, "Effect of biochar soil amendment on soil properties and yield of Sesame varieties in Lafia, Nigeria," American Journal of Experimental Agriculture, vol. 9, no. 4, pp. 1-8, 2015.

[41] H.-X. Chen, Z.-L. Du, W. Guo, and Q.-Z. Zhang, "Effects of biochar amendment on cropland soil bulk density, cation exchange capacity, and particulate organic matter content in the North China plain," Yingyong Shengtai Xuebao, vol. 22, no. 11, pp. 2930-2934, 2011.

[42] K. Y. Chan, L. van Zwieten, I. Meszaros, A. Downie, and S. Joseph, "Using poultry litter biochars as soil amendments," Australian Journal of Soil Research, vol. 46, no. 5, pp. 437-444, 2008.

[43] E. Amézketa, "Soil aggregate stability: a review," Journal of Sustainable Agriculture, vol. 14, no. 2-3, pp. 83-151, 1999.

[44] M. A. Arshad and G. M. Coen, "Characterization of soil quality: physical and chemical criteria," American Journal of Alternative Agriculture, vol. 7, no. 1-2, pp. 25-31, 1992.

[45] S. M. Aggelides and P. A. Londra, "Effects of compost produced from town wastes and sewage sludge on the physical properties of a loamy and a clay soil," Bioresource Technology, vol. 71 , no. 3, pp. 253-259, 2000.

[46] A. R. Dexter, G. Richard, D. Arrouays, E. A. Czyż, C. Jolivet, and O. Duval, "Complexed organic matter controls soil physical properties," Geoderma, vol. 144, no. 3-4, pp. 620-627, 2008.

[47] C. J. Bronick and R. Lal, "Soil structure and management: a review," Geoderma, vol. 124, no. 1-2, pp. 3-22, 2005.

[48] A. G. Alghamdi, "Biochar as a potential soil additive for improving soil physical properties-a review," Arabian Journal of Geosciences, vol. 11, no. 24, p. 766, 2018.

[49] J. Six, H. Bossuyt, S. Degryze, and K. Denef, "A history of research on the link between (micro) aggregates, soil biota, and soil organic matter dynamics," Soil and Tillage Research, vol. 79, no. 1, pp. 7-31, 2004.

[50] N. Ma, L. Zhang, Y. Zhang et al., "Biochar improves soil aggregate stability and water availability in a mollisol after 
three years of field application," PloS One, vol. 11, no. 5, Article ID e0154091, 2016.

[51] A. Mukherjee and R. Lal, "Biochar impacts on soil physical properties and greenhouse gas emissions," Agronomy, vol. 3, no. 2, pp. 313-339, 2013.

[52] S. M. Prober, J. Stol, M. Piper, V. Gupta, and S. A. Gunningham, "Enhancing soil biophysical condition for climate resilient restoration in mesic woodlands," Ecological Engineering, vol. 71, pp. 246-255, 2014.

[53] C. A. Igwe, F. O. R. Akamigbo, and J. S. C. Mbagwu, "Physical properties of soils of southeastern Nigeria and the role of some aggregating agents in their stability," Soil Science, vol. 160, no. 6, pp. 431-441, 1995.

[54] M. Tejada and J. L. Gonzalez, "Influence of organic amendments on soil structure and soil loss under simulated rain," Soil and Tillage Research, vol. 93, no. 1, pp. 197-205, 2007.

[55] T. M. Agbede, A. S. Odoja, L. N. Bayode, P. O. Omotehinse, I. Adepehin, and A. O. Adekiya, "Effects of biochar on soil properties and erosion potential in a degraded sandy soil," in Proceedings of the Global Symposium on Soil Erosion (GSER 2019), pp. 305-309, FAO, Rome, Italy, May 2019.

[56] J. E. Thies and M. C. Rillig, "Characteristics of biochar: biological properties," in Biochar for Environmental Management: Science and Technology Lehmann J., S. Joseph, Ed., pp. 85-105, Earthscan, London, UK, 2009.

[57] J. Lehmann, J. P. Da Silva Jr., M. Rondon et al., "Slash-andchar: a feasible alternative for soil fertility management in the Central Amazon?" in Proceedings of the 17th World Congress of Soil Science, pp. 1-12, Bangkok, Thailand, 2002.

[58] K. Mizuta, T. Matsumoto, Y. Hatate, K. Nishihara, and T. Nakanishi, "Removal of nitrate-nitrogen from drinking water using bamboo powder charcoal," Bioresource Technology, vol. 95, no. 3, pp. 255-257, 2004.

[59] J. D. Beaton, H. B. Peterson, and N. Bauer, "Some aspect of phosphate adsorption by charcoal," Soil Science Society of America Journal, vol. 24, no. 5, pp. 340-346, 1960.

[60] L. R. Radovic, C. Moreno-Castilla, and J. Rivera-Utrilla, "Carbon materials as adsorbents in aqueous solutions," in Chemistry and Physics of Carbon, L. R. Radovic, Ed., pp. 227-405, Marcel Dekker, New York, NY, USA, 2001.

[61] X. Jia, W. Yuan, and X. Ju, "Short report: effects of biochar addition on manure composting and associated $\mathrm{N}_{2} \mathrm{O}$ emissions," Journal of Sustainable Bioenergy Systems, vol. 5, no. 2, pp. 56-61, 2015.

[62] D. L. Jones, J. Rousk, G. Edwards-Jones, T. H. DeLuca, and D. V. Murphy, "Biochar-mediated changes in soil quality and plant growth in a three year field trial," Soil Biology and Biochemistry, vol. 45, pp. 113-124, 2012.

[63] S. P. Sohi, E. Krull, E. Lopez-Capel, and R. Bol, "A review of biochar and its use and function in soil," Advances in Agronomy, vol. 105, pp. 47-82, 2010.

[64] C. M. Preston and M. W. I. Schmidt, "Black (pyrogenic) carbon: a synthesis of current knowledge and uncertainties with special consideration of boreal regions," Biogeosciences, vol. 3, no. 4, pp. 397-420, 2006.

[65] K. Sawada, S. Funakawa, K. Toyota, and T. Kosaki, "Potential nitrogen immobilization as influenced by available carbon in Japanese arable and forest soils," Soil Science and Plant Nutrition, vol. 61, no. 6, pp. 917-926, 2015.

[66] C. Njoku, C. N. Mbah, P. O. Igboji, J. N. Nwite, C. C. Chibuike, and B. N. Uguru, "Effect of biochar on selected soil physical properties and maize yield in an ultisol in Abakaliki southeastern Nigeria," Global Advanced Research
Journal of Agricultural Science, vol. 4, no. 12, pp. 864-870, 2015.

[67] P. G. Oguntunde, M. Fosu, A. E. Ajayi, and N. van de Giesen, "Effects of charcoal production on maize yield, chemical properties and texture of soil," Biology and Fertility of Soils, vol. 39, no. 4, pp. 295-299, 2004.

[68] V. Alling, S. E. Hale, V. Martinsen et al., "The role of biochar in retaining nutrients in amended tropical soils," Journal of Plant Nutrition and Soil Science, vol. 177, no. 5, pp. 671-680, 2014.

[69] C.-H. Cheng, J. Lehmann, J. E. Thies, S. D. Burton, and M. H. Engelhard, "Oxidation of black carbon by biotic and abiotic processes," Organic Geochemistry, vol. 37, no. 11, pp. 1477-1488, 2006.

[70] B. Singh, B. P. Singh, and A. L. Cowie, "Characterisation and evaluation of biochars for their application as a soil amendment," Soil Research, vol. 48, no. 7, pp. 516-525, 2010.

[71] J. Major, J. Lehmann, M. Rondon, and C. Goodale, "Fate of soil-applied black carbon: downward migration, leaching and soil respiration," Global Change Biology, vol. 16, no. 4, pp. 1366-1379, 2010.

[72] S. Jeffery, D. Abalos, M. Prodana et al., "Biochar boosts tropical but not temperate crop yields," Environmental Research Letters, vol. 12, no. 5, Article ID 053001, 2017.

[73] T. G. Reichenauer, S. Panamulla, S. Subasinghe, and B. Wimmer, "Soil amendments and cultivar selection can improve rice yield in salt-influenced (tsunami-affected) paddy fields in Sri Lanka," Environmental Geochemistry and Health, vol. 31, no. 5, pp. 573-579, 2009.

[74] M. Yamato, Y. Okimori, I. F. Wibowo, S. Anshori, and M. Ogawa, "Effects of the application of charred bark of acacia mangiumon the yield of maize, cowpea and peanut, and soil chemical properties in South Sumatra, Indonesia," Soil Science and Plant Nutrition, vol. 52, no. 4, pp. 489-495, 2006.

[75] S. O. Tagoe, T. Horiuchi, and T. Matsui, "Effects of carbonized and dried chicken manures on the growth, yield, and $\mathrm{N}$ content of soybean," Plant and Soil, vol. 306, no. 1-2, pp. 211-220, 2008. 